\title{
Effects of parental divorce on children
}

Though divorce rates have been more or less stable in Britain over the past decade and the steep increases of earlier years have levelled off, concern about the consequences of divorce for both adults and children has remained high. There is continued interest too in practical responses. Conciliation services are now an established part of the scene, albeit very inadequately supported financially, and are developing a wide range of approaches. ${ }^{1}$ There is also the prospect of a new divorce law which is intended to encourage negotiated settlement of conflicts.

The distress and difficulties that children experience as they become aware that their parents may separate, and which persist through the often long and drawn out process of divorce, have been well described..$^{2-4}$ Research has made a good deal of headway in identifying the factors which are important for children's adjustment. Where children maintain good relationships with both parents the negative effects of divorce are mitigated. But breaks and continuing change in these relationships can be associated with low self esteem, depression and anxiety, acting out behaviour, and poor relationships with peers. ${ }^{5-7}$ Continuing conflict between the parents after a divorce has also been found to result in negative outcomes for children possibly because the conflicts tend to erode the quality of parent-child relationships. ${ }^{8}$ Joint custody arrangements have often been promoted as helpful to children and, although research evaluation is still far from adequate, the indications are that it is helpful insofar as it may help to maintain good relationships between the child and both parents.

Parental health often suffers as a marriage ends. ${ }^{9}$ Poor health and particularly poor psychological health may reduce the capacity to be an effective parent, and this may also be an important factor in children's adjustment.

Research in both Britain ${ }^{10}$ and the USA $^{11}$ has drawn attention to the sharp drop in income to households with children after divorce. Probably the majority of the poorest homes with children in Britain have been created through a divorce and, of course, as is well known, poverty has very detrimental effects on the development of children. Government plans 'to make fathers pay' seem unlikely to have a significant effect on the situation as the main consequences would seem to be to create a net flow of money from fathers to the exchequer.

There is growing research interest in the effects of remarriage on children, but we are still some way from obtaining a consistent picture. Though household incomes will tend to rise with remarriage, the arrival of a new adult may bring further difficulties for children and exacerbate their behavioural problems. ${ }^{12}{ }^{13}$ Some of this effect may arise because remarriage is usually associated with a reduction in contact with the non-resident parent. ${ }^{14}$

Increasingly divorce researchers are moving away from the smaller scale, more clinical studies, to larger more representative samples. Although these provide better grounded evidence about outcomes, the lack of detailed information about family relationships makes the interpretation of some findings difficult. Allison and Furstenberg have analysed data from the 'National Survey of Children' (a nationally representative sample of 1197 children in the USA). ${ }^{15}$ Their results suggest that marital dissolution has negative and longlasting effects on behaviour, psychological wellbeing, and academic performance. In magnitude, the effects were found to be slightly smaller than sex differences (so that for example the difference between boys and girls on measures of academic performance is slightly larger than the difference between those with married parents and those with separated/divorced parents), but larger than those associated with other demographic variables such as mother's education.

In contrast to many other studies, Allison and Furstenberg found no evidence that boys were more affected by their parents' divorce than were girls. There was, however, evidence that effects were larger for those children who were very young at the time of their parents' separation. This finding is consistent with that of Wallerstein and Kelly, whose detailed interviews with the parents and children from 60 divorcing families in California also suggested that younger children (3-5 years of age) have particular difficulty adjusting to parental divorce because their limited cognitive capacities prevent them from fully understanding the meaning of the divorce. ${ }^{2}$ This can lead to fear of abandonment, unusual fantasies, emotional neediness, and behaviour problems.

Perhaps the best sources of British data with which to examine the effects of parental divorce on children are the national cohort studies. The National Child Development Survey, which is a cohort study of all the children born in Britain in one week of March 1958, had followed up children from their birth, with data collected at age $7,11,16$, and most recently at age 23 . Of the original cohort of around 17000 births, approximately 700 children had experienced parental divorce before the age 16 data collection.

The longitudinal nature of the data has enabled us to analyse the children's behaviour and educational performance both before and after the parental divorce. ${ }^{13}$ These analyses suggest tht some of the problems for children that have previously been attributed to parental divorce or separation may in fact be present before the separation. Measures of mathematics and reading ability and measures of disruptive behaviour and unhappy and worried behaviour have been used on children at age 7 and at age 16. It was found that both boys and girls whose parents divorced when they were between 7 and 16 years old obtained worse scores on each of these four measures both at age 16, after the divorce, and also at age 7 before the divorce (in many cases several years before), and while the parents were still living together.

Most, but certainly not all, divorces are preceded by a period of marital conflict and this has been found to be associated with behavioural problems in children. ${ }^{16}$ But there are several other possible explanations for our results. For instance, it has been suggested that adults with poor psychological health are more likely to separate. Or the growing marital problems may have negative effects on parent-child relationships.

The cohort of children born in one week in 1946 (The 
National Survey of Health and Development) has been followed up from birth to age 36 and analyses suggests that some effects of parental divorce may persist into adulthood. The effect of divorce on educational achievement results in an increased likelihood of children leaving school without qualifications and an appreciable reduction in their chances of entering higher education. Not surprisingly there are also indications of reduced earnings and occupational status in adulthood. ${ }^{17}$ The lower educational achievement is also apparent in the 1958 cohort. There are also indications from analyses of the 1946 cohort of a slight increase in the probability of divorce in young adulthood, perhaps associated with a tendency towards earlier marriage. ${ }^{18}$

There is little doubt that parental divorce can be a major disruption in children's lives that for some has long term consequences. But with the growth of services that aim to help parents settle their differences at divorce there is some hope that such effects may be reduced for future generations, particularly if these were coupled with more effective means of reducing the poverty that divorce brings for too many children.

B JANE ELLIOTT

MARTIN P M RICHARDS

Child Care and Development Group,

Cambridge University,

Free School Lane,

Cambridge $C B 23 R F$
1 Richards MPM. Divorce Cambridge style: new developments in conciliation. Family Law 1990;21:436-8.

2 Wallerstein JS, Kelly J. Surviving the break-up: how children and parents cope with divorce. New York: Basic Books, 1980.

3 Mitchell A. Children in the middle. London: Tavistock, 1985

4 Burgoyne J, Ormrod R, Richards MPM. Divorce matters. London: Penguin Books, 1987.

5 Hess RD, Camara KA. Post-divorce family relationships as mediating factors in the consequen :s of divorce for children. Fournal of Social Issues 1979;35: 79-96.

6 Hetherington EM, Cox M, Cox R. Effects of divorce on parents and children. In: Lamb ME, ed. Non-traditional families: parenting and child development. In: Lamb ME, ed. Non-traditional families: parenting

7 Hetherington EM, Arasteh JD, eds. Impact of divorce, single parenting, and stepparenting on children. Hillsdale, NJ: Laurence Erlbaum Associates, 1988.

8 Emery RE. Interparental conflict and the children of discord and divorce. Psychol Bull 1982;92:310-30.

9 Kitson GC, Morgan LA. The multiple consequences of divorce: a decade review. Fournal of Marriage and the Family 1990;52:913-24

10 Maclean M. Households after divorce: the availability of resources and their impact on children. In: Brannen J, Wilson G, eds. (iive and take in families: studies in resource distribution. London: Allen and Unwin, 1987.

11 Weitzman LJ. The divorce revolution. New York: The Free Press, 1985.

2 Baydar N. Effects of parental separation and reentry into union on the emotional well-being of children. Foumal of Marriage and the Family 1988; 50:967-81.

13 Elliott BJ, Richards MPM. Children and divorce: educational performance, and behaviour, before and after parental separation. Intemational foumal of Law and the Familv 1991 (in press).

14 Seltzer JA, Bianchi SM. Children's contact with absent parents. Fournal of Marriage and the Family 1988;50:663-77.

15 Allison PD, Furstenberg FF. How marital dissolution affects children: variations by age and sex. Developmental Psvchologv 1989:25:540-9.
tistion

6 Rutter M. Matemal deprivation reassessed ind Ed London. Penguin, 1981.

7 Maclean M, Wadsworth MEJ. The interest of children after parental divorce: a long term perspective. International fournal of Lati and the Family 1988:2: $155-66$

18 Kuh D, Maclean M. Women's childhood experience of parental separation and their subsequent health and socioeconomic status in adulthood. f Biosoc Sci 1990;22:1-15. 